\title{
The dorsal shell wall structure of Mesozoic ammonoids
}

Gregor Radtke and Helmut Keupp

Acta Palaeontologica Polonica 62 (1), 2017: 59-96 doi:https://doi.org/10.4202/app.00263.2016

The study of pristine preserved shells of Mesozoic Ammonoidea shows different types of construction and formation of the dorsal shell wall. We observe three major types: (i) The vast majority of Ammonoidea, usually planispirally coiled, has a prismatic reduced dorsal shell wall which consists of an outer organic component (e.g., wrinkle layer), which is the first layer to be formed, and the subsequently formed dorsal inner prismatic layer. The dorsal mantle tissue suppresses the formation of the outer prismatic layer and nacreous layer. With the exception of the outer organic component, secretion of a shell wall is omitted at the aperture. A prismatic reduced dorsal shell wall is always secreted immediately after the hatching during early teleoconch formation. Due to its broad distribution in (planispiral) Ammonoidea, the prismatic reduced dorsal shell wall is probably the general state. (ii) Some planispirally coiled Ammonoidea have a nacreous reduced dorsal shell wall which consists of three mineralized layers: two prismatic layers (primary and secondary dorsal inner prismatic layer) and an enclosed nacreous layer (secondary dorsal nacreous layer). The dorsal shell wall is omitted at the aperture and was secreted in the rear living chamber. Its layers are a continuation of an umbilical shell doubling (reinforcement by additional shell layers) that extends towards the ventral crest of the preceding whorl. The nacreous reduced dorsal shell wall is formed in the process of ontogeny following a prismatic reduced dorsal shell wall. (iii) Heteromorph and some planispirally coiled taxa secrete a complete dorsal shell wall which forms a continuation of the ventral and lateral shell layers. It is formed during ontogeny following a prismatic reduced dorsal shell wall or a priori. The construction is identical with the ventral and lateral shell wall, including a dorsal nacreous layer. The wide distribution of the ability to form dorsal nacre indicates that it is a plesiomorphic trait which either was passed on from gyrocone ammonoid ancestors or (re-)developed in post-Triassic ammonoids.

Key words: Ammonoidea, internal structure, dorsal shell wall, wrinkle layer, spiral ornament, Ritzstreifen, Mesozoic.

Gregor Radtke [gradtke@zedat.fu-berlin.de] and Helmut Keupp [keupp@ zedat.fu-berlin.de], Department of Earth Sciences, Freie Universität Berlin, Malteserstraße 74-100, Building D, 12249 Berlin, Germany. 
This is an open-access article distributed under the terms of the Creative Commons

Attribution License (for details please see creativecommons.org), which permits unrestricted use, distribution, and reproduction in any medium, provided the original author and source are credited.

For Full text $(8,865.5 \mathrm{kB})$ 